\title{
Litter Accumulation in a Eucalyptus grandis Plantation, Rio Grande do Sul, Brazil
}

\author{
Fernanda Dias dos Santos ${ }^{1}$ (1) 0000-0002-6337-3061 \\ Roberta Aparecida Fantinel ${ }^{1}$ (1) 0000-0002-1827-7943 \\ Camila Andrzejewski ${ }^{1}$ (i) 0000-0001-8316-2483 \\ Elke Lima dos Santos ${ }^{1}$ (D) 0000-0002-9944-4343 \\ Dayanna do Nascimento Machado ${ }^{1}$ (1) 0000-0001-9837-5369 \\ Mauro Valdir Schumacher ${ }^{1}$ (D) 0000-0003-3277-5671
}

\begin{abstract}
This study aimed at quantifying the accumulation of litter in formative compartments (bark, branches, leaves, and miscellaneous) above the soil in a 23-year-old Eucalyptus grandis plantation, located on the campus of the Universidade Federal de Santa Maria, Rio Grande do Sul. We installed four parallel plots on the settlement lines, measuring $3.0 \mathrm{~m} \times 6.0 \mathrm{~m}$. In order for litter collection, we utilized a $25 \mathrm{~cm} \times 25 \mathrm{~cm}$ iron frame and randomly collected 15 samples of each plot, totaling 60 samples. The burlap consisted predominantly of branches (39\%) and miscellaneous (29\%) fraction, followed by leaves (23\%) and bark (6\%). Such accumulation may be associated with the age of the Eucalyptus grandis, the density of the forest, and the stability achieved by the plantation.
\end{abstract}

Keywords: planted forest, organic matter, nutrient cycling.

\section{INTRODUCTION AND OBJECTIVES}

Research on nutrient cycling has been developed to understand the process of nutrient transfer between soil and vegetation over a given period of time. This process plays a key role in maintaining the productivity of the forest ecosystems, with respect to soils with low nutrient content and weathering (Schumacher et al., 2004).

Most of the energy and nutrients absorbed in forest ecosystems are accumulated in the soil for the maintenance and growth of tree canopy structures (branches, leaves, flowers, seeds, and fruits). Due to evolutionary factors, or in response to environmental stress, plant species periodically replace these structures through a process referred to in the literature as "nutrient cycling". Andrade et al. (1999) stated that nutrient cycling in a forest ecosystem consists of the movement of nutrients between its compartments and the transference from the analyzed compartments to the ecosystem. The nutrient cycling has its genesis predominantly in the production of burlap. This litter releases organic and inorganic compounds into the soil, depending on the composition of the organic matter and the nutrients present in the structures of the tree canopies. According to Neves et al. (2001), burlap content varies depending on the species, the age of the trees, and the type of planted or natural forest, among other aspects.

The decomposition process regulates burlap accumulation and nutrient cycling in forest ecosystems, and is fundamental for its maintenance (Pinto et al., 2016). The decomposition of canopy structures and microorganisms comprise the main source of nutrients for the forest ecosystem. Litter, according to Piovesan et al. (2012), is composed primarily of leaves, branches, bark, fruits, stems, flowers, and amorphous material. In accordance with Barbosa and Faria (2006), burlap consists of organic material of plant and animal origin, deposited on the soil, with different stages of decomposition, which represents a form of entry and subsequent increase of organic matter in the soil. It is important to highlight that a number of factors are involved in burlap production, including vegetation type, altitude, latitude, precipitation, temperature, luminosity regimes, relief, deciduousness, successional stage, hydric availability, and soil characteristics (Calvi et al., 2009).

\footnotetext{
${ }^{1}$ Universidade Federal de Santa Maria (UFSM), Santa Maria, RS, Brasil
} 
Litter nutrient uptake, according to Reissmann and Wisniewski (2000), represents an essential flow to meet the nutritional demand of trees. Mariano et al. (2007) stated that, from the evaluation of litterfall, it is possible to indirectly estimate the route of nutrient absorption by the plants, since, when the ecosystems are in equilibrium, the amount of nutrients transferred through leaf fall is equivalent to that absorbed by the plants.

The layer of burlap that accumulates in the soil, according to Schumacher et al. (2004), works like a sponge. In other words, it has the capacity to retain rainwater, reducing evaporation and sudden changes in soil temperature; increase the amounts of organic matter, avoiding erosion and improving soil structure; and promote the nutrient cycling in the ecosystem. In the case of high-growth forest systems, namely species of the genus Eucalyptus, the evaluation of nutrient availability through litter is fundamental to assess the availability of nutrients in the soil (Ferreira et al., 2007).

Knowledge of the amount of litter deposited in the Eucalyptus sp. populations is necessary for the sustainable management of soils and mineral resources, so as not to compromise the nutritional support capacity of the soil, in order to maintain the balanced production of direct and indirect benefits of these planted forests (Brun et al., 2013). In face of the above, this study aimed to quantify the accumulation of burlap in the formative compartments (bark, branches, leaves, and miscellaneous) on the soil in a population of Eucalyptus grandis, located on the campus of the Universidade Federal de Santa Maria, Rio Grande do Sul.

\section{MATERIALS AND METHODS}

We conducted this study in a test area where research is carried out in the areas of forestry and forest management, located on the Main Campus of the Universidade Federal de Santa Maria (UFSM), in the municipality of Santa Maria, RS (Figure 1).

According to the Köppen classification, the area is classified as of subtropical Cfa climate, which is characterized by an average annual temperature of $19{ }^{\circ} \mathrm{C}$. The rains are well distributed throughout the year, with average annual rainfall ranging between 1,400 and 1,900 $\mathrm{mm}$ (Alvares et al., 2013; Moreno, 1961).

We conducted the experiment in a 23-year-old Eucalyptus grandis plantation. The seedlings utilized for the implantation of the Eucalyptus settlement were obtained in 1993 and were planted with $3.0 \mathrm{~m} \times 2.0 \mathrm{~m}$ spacing. Data collection was performed in September 2016, in which the precipitation was $57.4 \mathrm{~mm}$, and abrupt temperature fluctuations occurred typically, ranging from 9.7 to $21.1^{\circ} \mathrm{C}$ (Irga, 2017).

We installed four parallel plots on the settlement lines, measuring $3.0 \mathrm{~m} \times 6.0 \mathrm{~m}$. In order for litter collection, we utilized a $25 \mathrm{~cm} \times 25 \mathrm{~cm}$ iron frame, following the methodology proposed by Corrêa et al. (2016), and randomly collected 15 samples from each plot, totaling 60 samples (Figure 2).

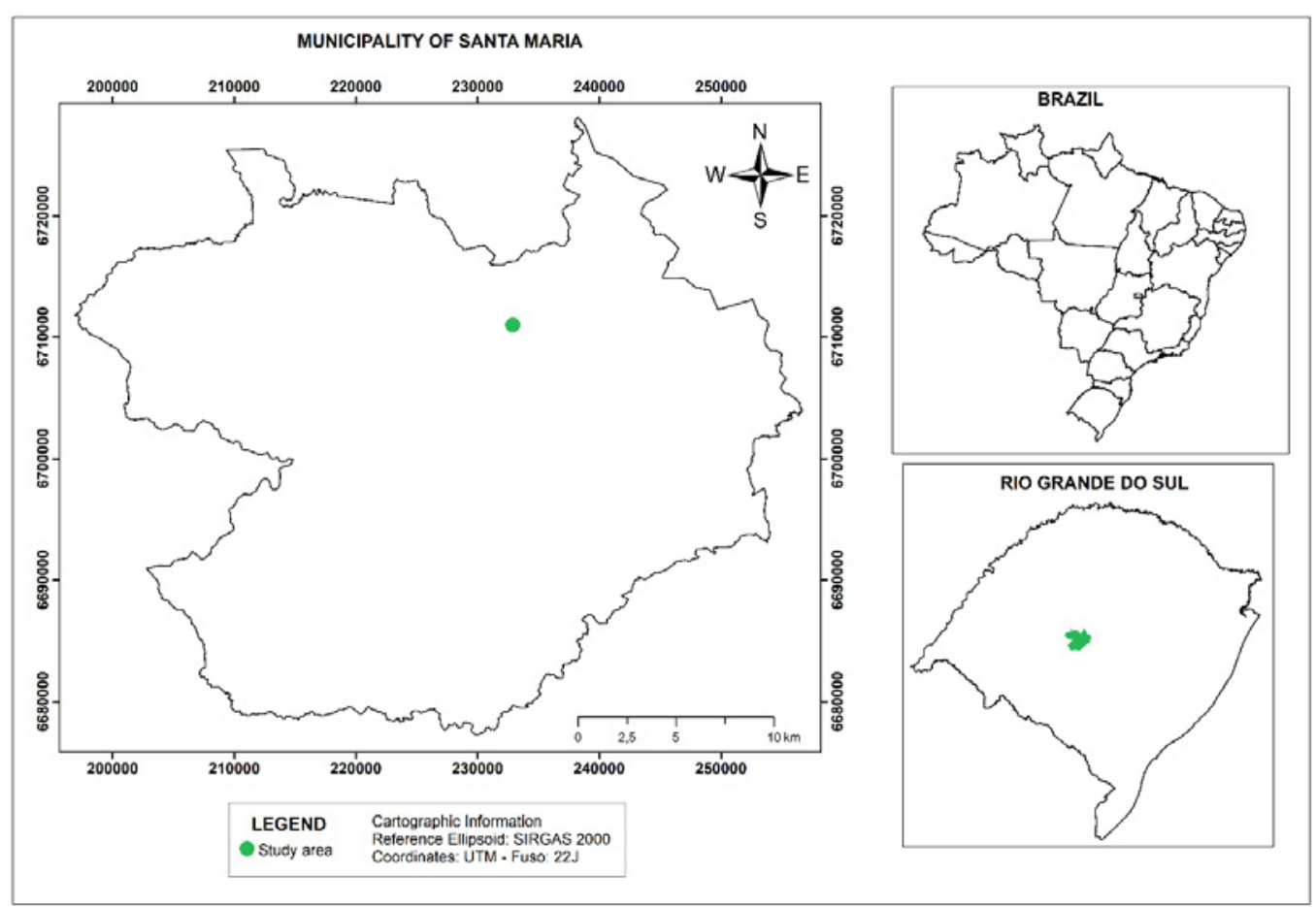

Figure 1. Location map of the study area, Santa Maria, RS, Brazil. 

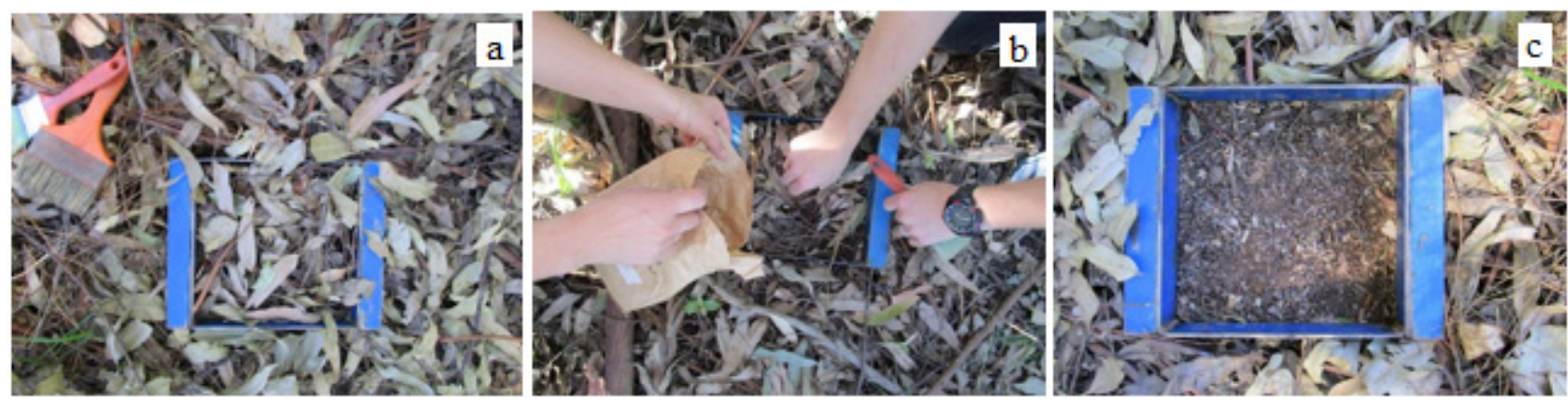

Figure 2. Collection of litter samples in a settlement of Eucalyptus grandis.

(a) mold; (b) removal of the material; (c) area after material removal, Santa Maria, RS, Brazil.

After collection, we packaged the material in paper bags, identified and sent them to the Forest Ecology Laboratory of the Universidade Federal de Santa Maria. We segregated the 60 samples into the following fractions: leaves, branches, bark, and miscellaneous. Next, we separated the samples, placed them into bags containing each of the categories and identified them with the plot, sample number, and the initial of the corresponding fraction. Afterward, we put them into an air-renewal circulation oven at a temperature of $70{ }^{\circ} \mathrm{C}$ for 72 hours.

We performed the weighing process of the 240 samples on an analytical scale with $0.01 \mathrm{~g}$ precision. Afterward, we ground them, obtaining a homogeneous sample. In other words, all the samples of the same fraction taken from the same plot were packed in plastic bags, from which milled portions were placed into plastic containers.

Thus, after grinding, we obtained a sample of each category for each of the plots, totaling 16 samples. These were sent to the laboratory of chemical analysis, where information, such as the amount of macro and micronutrients for each of the fractions (leaves, branches, bark, and miscellaneous), was obtained.

We submitted the information regarding the burlapforming fractions (leaves, bark, branches, and miscellaneous), inside and between the plots, to analysis of variance (Anova). The data were transformed by $y=$ to meet the assumptions of normality and homogeneity. Afterward, we applied the Tukey mean test at $5 \%$ probability using the Sisvar program, version 5.6 (Ferreira, 2011).

\section{RESULTS AND DISCUSSION}

The accumulated litter in the Eucalyptus grandis forest retained $17.61 \mathrm{Mg} \mathrm{ha}^{-1}$ of estimated dry mass. In the study by Vogel et al. (2014), the authors verified a deposition of $6.53 \mathrm{Mg} \mathrm{ha}^{-1}$ year $^{-1}$ of burlap in a forest fragment where human interference has been absent for more than 50 years, in which the leaves were responsible for $70 \%$, followed by the miscellaneous group with $18.6 \%$, and the fine branches group with $11.4 \%$.

In this study, the branch fraction contributed the most to the total production of burlap, with $6.91 \mathrm{Mg} \mathrm{ha}^{-1}$ (39\%), although it did not differ considering the average amount of deposition of the miscellaneous $\left(5.02 \mathrm{Mg} \mathrm{ha}^{-1} ; 29 \%\right)$ and leaf $\left(4.06 \mathrm{Mg} \mathrm{ha}^{-1} ; 23 \%\right)$ fractions. The bark fraction was the smallest regarding total litter deposition (1.62 $\left.\mathrm{Mg} \mathrm{ha}^{-1} ; 9 \%\right)$, as shown in Figure 3. This result corroborates those obtained in the study by Carvalho et al. (2015), in which the branch and miscellaneous fractions retained high coefficients of variation ( $20.45 \%$ and $34.15 \%$, respectively), when compared to the leaf fraction $(1.31 \%)$.

Gatto et al. (2014) estimated the biomass of a five-year-old settlement of Eucalyptus urophylla $\times$ Eucalyptus grandis, in which they reported a production of $57.36 \mathrm{Mg} \mathrm{ha}^{-1}$ of wood; $8.08 \mathrm{Mg} \mathrm{ha}^{-1}$ of branches, and $5.03 \mathrm{Mg} \mathrm{ha}^{-1}$ of bark, totaling $69.19 \%$ of the total biomass, and 4.02 $\mathrm{Mg} \mathrm{ha}^{-1}$ of leaves. When evaluating the biomass in a four-year-old Eucalyptus sp. plantation, Schumacher et al. (2011) obtained the following results: leaves $\left(3.96 \mathrm{Mg} \mathrm{ha}^{-1}\right)$, branches $\left(8.57 \mathrm{Mg} \mathrm{ha}^{-1}\right)$, trunk wood $\left(22.5 \mathrm{Mg} \mathrm{ha}^{-1}\right)$, and bark (3.46 Mg ha-1). Vieira et al. (2013), when working with Eucalyptus urophylla $\times$ Eucalyptus globulus, with ages ranging from 6 to 9 years during sample collection, found accumulated litter values of $14.0 \mathrm{Mg} \mathrm{ha}^{-1}$. Santos et al. (2014) worked with the same species aged four and five years, in the municipality of São Gabriel, RS, where burlap production ranged from 12.7 to $12.0 \mathrm{Mg} \mathrm{ha}^{-1}$, respectively. Differences regarding the mentioned assessments and our study can be noticed. However, comparisons between accumulated litter values are difficult since the accumulation of burlap is influenced by several factors, such as soil conditions (soil type), temperature, precipitation, climate, terrain conditions, studied species, and adopted methodologies (Godinho et al., 2014). 


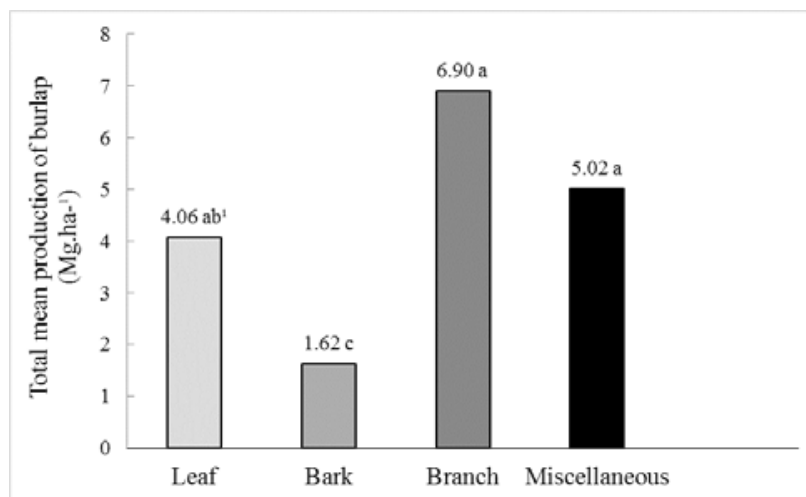

Figure 3. Litter production in each compartment (fraction) in a settlement of Eucalyptus grandis, Santa Maria, RS, Brazil.

${ }^{(1)}$ Means followed by the same lowercase letter do not differ between each other by the Tukey test at a $5 \%$ probability of error.

In general, much of the litter-forming biomass accumulated on the soil is composed of leaves, which increases as the forest ages. However, these values may undergo variations since, at some point, leaf fall decreases due to the increment in the fall of branches and bark (Godinho et al., 2015), as verified in our study, where the highest proportion of the litter was composed of branches. Furthermore, according to these authors, larger amounts of woody material forming the burlap layer can be attributed to the action of heavy rains or winds. Hernández et al. (2009) evaluated a nine-year-old Eucalyptus dunnii population, planted in Algorta, in Uruguay, and verified total biomass production above the soil in the amount of $236 \mathrm{Mg} \mathrm{ha}^{-1}$.

Regarding the deposition of the litter-forming fractions, when analyzed within each plot, we observed greater means of deposition ( $\left.\mathrm{Mg} \mathrm{ha-}{ }^{1}\right)$ between the branch and miscellaneous fractions in plot 1 , without statistical differences between them (Table 1). In plot 2, the mean deposition $\left(\mathrm{Mg} \mathrm{ha}^{-1}\right)$ of the branches, leaves, and miscellaneous fractions were the same.

In plots 3 and 4, we reported the highest average deposition values $\left(\mathrm{Mg} \mathrm{ha}^{-1}\right)$ in the branch fraction. The bark fraction retained a significantly lower amount of burlap deposition, except in plot 3, where it did not differ considering the mean amount of deposition of the miscellaneous fraction.

Among the plots, we observed higher coefficients of variation in the miscellaneous and bark fractions when compared with the leaves and branches. Such result can be explained since we collected the litter-forming fractions in the beginning of September, which corresponds to the end of the winter season. This corroborates the results found by Carvalho et al. (2015) in a settlement of Eucalyptus saligna, where they verified high coefficients of variation for the branch and miscellaneous fractions when compared to the leaf fraction. According to the authors, the lowest amount of leaves deposited on the soil is associated with the period of sample collection, which was performed in the winter. The greater production of leaves occurs in the late spring and early summer.

In contrast with the previously mentioned results, the burlap of a population of Eucalyptus urophylla $\times$ Eucalyptus globulus maidenii, between six and seven years of age, was verified to be predominantly composed of leaves (60\%) (Schumacher et al., 2013). The authors' findings denote a low influence of climatic variables regarding the amount of litter produced in the studied period (January 2007 to December 2008).

Table 1. Averages of the litter fractions: leaves, bark, branches, and miscellaneous for the different treatments in a settlement of Eucalyptus grandis, Santa Maria, RS, Brazil.

\begin{tabular}{|c|c|c|c|c|c|}
\hline \multirow{2}{*}{ Treatments } & \multicolumn{4}{|c|}{ Average litter fractions (Mg ha- $\left.{ }^{-1}\right)$} & \multirow[b]{2}{*}{ Cv\% } \\
\hline & Leaves & Bark & Branches & Miscellaneous & \\
\hline $\mathbf{P 1}^{1}$ & $3.04 \mathrm{bB}^{2}$ & $1.43 \mathrm{cA}$ & $8.79 \mathrm{aA}$ & $9.56 \mathrm{aA}$ & 28.7 \\
\hline $\mathbf{P 2}$ & $4.92 \mathrm{abA}$ & $1.82 \mathrm{cA}$ & $6.45 \mathrm{aB}$ & $3.61 \mathrm{bB}^{*}$ & 22.7 \\
\hline P3 & $4.28 \mathrm{bA}$ & $1.64 \mathrm{cA}$ & $6.33 \mathrm{aB}$ & $2.84 \mathrm{cB}$ & 23.2 \\
\hline $\mathbf{P 4}$ & $4.00 \mathrm{bAB}$ & $1.59 \mathrm{cA}$ & $6.04 \mathrm{aB}$ & $4.05 \mathrm{bB}^{*}$ & 21.5 \\
\hline $\mathrm{Cv} \%$ & 13.3 & 28.4 & 16.4 & 36.4 & \\
\hline
\end{tabular}

(1)P1: plot 1; P2: plot 2; P3: plot 3; P4: plot 4; Cv\%: coefficient of variation.

${ }^{(2)}$ Means followed by the same lowercase letter in a row do not differ among the litter fractions in the treatment according to the Tukey mean test. 


\section{CONCLUSIONS}

The analyzed burlap consisted primarily of branches (39\%) and the miscellaneous fraction (29\%). This accumulation may be related to the age of the Eucalyptus grandis (23 years), forest density, and the stability reached by the settlement.

The leaf fraction was minimally representative $(23 \%)$ in the accumulated litter. This fact may have occurred due to the period of collection, which was performed at the end of winter, in which leaf fall is reduced. The bark fraction was also poorly representative, contributing only with $6 \%$ in the accumulation of burlap.

\section{Submission status}

Received: 31 Oct. 2017

Accepted: 22 Aug. 2018

Associate editor: Marcos Gervásio Pereira

(D) 0000-0002-1402-3612

\section{Correspondence to Fernanda Dias dos Santos}

Universidade Federal de Santa Maria (UFSM), Av. Roraima, 1.000, CEP 97105-900, Santa Maria, RS, Brasil

e-mail: fernandaengflor@gmail.com

\section{References}

Alvares CA, Stape JL, Sentelhas PC, Gonçalves JLM, Sparovek G. Köppen's climate classification map for Brazil. Meteorologische Zeitschrift 2013; 22(6): 711-728. 10.1127/0941-2948/2013/0507

Andrade AG, Caballero SSU, Faria SM. Ciclagem de nutrientes em ecossistemas florestais. Rio de Janeiro: Embrapa Solos; 1999.

Barbosa JHC, Faria SMD. Aporte de serapilheira ao solo em estágios sucessionais florestais na reserva biológica de Poço das Antas, Rio de Janeiro, Brasil. Rodriguésia 2006; 3(57): 461-476. 10.1590/2175-7860200657306

Brun LJ, Ferraz MO, Araújo EF. Relação entre o acúmulo de serapilheira sobre o solo e variáveis dendrométricas em povoamento híbrido de Eucalyptus urophylla $\times$ E. globulusmaidenii, em Eldorado do Sul/RS. Ecologia e Nutrição Florestal 2013; 1(1): 24-31. 10.13086/2316-980x.v01n01a03

Calvi GP, Pereira MG, Espíndula A Jr. Produção de serapilheira e aporte de nutrientes em áreas de floresta Atlântica em Santa Maria de Jetibá, ES. Ciência Florestal 2009; 19(2): 131-138. $10.5902 / 19805098404$

Carvalho RR, Andrade VHF, Lener J, Basso S, Manfio MM. Estimativa dos micronutrientes na serapilheira acumulada de um povoamento de Eucalyptus saligna (Smith.), São Gabriel-RS. Enciclopédia Biosfera 2015; 11(21): 976-983.
Corrêa RS, Schumacher MV, Momolli DR. Deposição de serapilheira e micronutrientes ao longo das estações do ano em um plantio de eucalipto estabelecido sobre pastagem natural degradada no bioma pampa. Scientia Forestalis 2016; 44(110): 435-442. 10.18671/scifor.v44n110.16

Ferreira DF. Sisvar: a computer statistical analysis system. Ciência e Agrotecnologia 2011;35(6): 1039-1042.10.1590/S1413-70542011000600001 Ferreira RLC, Lira MA Jr, Rocha MS, Santos MVF, Andrade M, Barreto LP. Deposição e acúmulo de matéria seca e nutrientes em serapilheira em um bosque de sabiá (Mimosa caesalpiniifolia Benth.). Revista Árvore 2007; 31(1): 7-12. 10.1590/S0100-67622007000100002 Gatto A, Bussinger AP, Ribeiro FC, Azevedo GB, Bueno MC, Monteiro MM, Souza PF. Ciclagem e balanço de nutrientes no sistema solo-planta em um plantio de Eucalyptus sp. no Distrito Federal. Revista Brasileira de Ciência do Solo 2014; 38(3): 879-887. 10.1590/S0100-06832014000300019

Godinho TO, Caldeira MVW, Rocha JHT, Caliman JP, Trazzi, PA. Quantificação de biomassa e nutrientes na serapilheira acumulada em trecho de Floresta Estacional Semidecidual Submontana, ES. Cerne 2014; 20(1): 11-20. 10.1590/S0104-77602014000100002 Godinho TO, Caldeira MVW, Brun EJ. Ciclagem de nutrientes via serapilheira em ecossistemas florestais naturais no Brasil. In: Faria ABC, Brun EJ, Ferrari F, organizers. Ciências Florestais e Biológicas (CIFLORBIO). Curitiba: Editora UTFPR; 2015. p. 13-53. Hernández J, Del Pino A, Salvo L, Arrarte G. Nutrient export and harvest residue decomposition patterns of a Eucalyptus dunnii Maiden plantation in temperate climate of Uruguay. Forest Ecology and Management 2009; 258(2): 92-99. 10.1016/j.foreco.2009.03.050 Instituto Rio Grandense do Arroz - IRGA. Médias climatológicas [Internet]. 2017 [cited 2017 Mar. 28]. Available from: https://irga. rs.gov.br/medias-climatologicas Mariano KRS, Amorim SMC, Mariano CAS Jr, Silva KKA, Souza RJM. Aporte de nutrientes ao solo via produção de serapilheira pela espécie Coccoloba rosea Meisn. Revista Brasileira de Biociências 2007; 5(Suppl 1): 384-386.

Moreno JA. Clima do Rio Grande do Sul. Porto Alegre: Secretaria da Agricultura; 1961.

Neves EJM, Martins EG, Reissmann CB. Deposição de serapilheira e de nutrientes de duas espécies da Amazônia. Boletim de Pesquisa Florestal 2001; 7(43): 47-60.

Pinto HCA, Barreto PAB, Da Gama-Rodrigues EF, De Oliveira FGRB, De Paula A, Ranulfo AA. Decomposição da serapilheira foliar de floresta nativa e plantios de Pterogyne nitens e Eucalyptus urophylla no Sudoeste da Bahia. Ciência Florestal 2016; 26(4): 1141-1153. 10.5902/1980509825105

Piovesan G, Schumacher MV, Vieira M, Lopes VG, Welter C. Deposição de serapilheira em povoamento de Pinus. Pesquisa Agropecuária Tropical 2012; 42(2): 206-211. 10.1590/S1983-40632012000200012 Reissmann CB, Wisniewski, C. Aspectos nutricionais de plantios de Pinus. In: Goncalves JL, Benedetti V, editors. Nutrição e fertilização florestal. Piracicaba: IPEF; 2000. p. 135-166. 
Santos JC, Schumacher MV, Witschoreck R, Araújo EF, Lopes VG. Nutrientes na serapilheira acumulada em um povoamento de Eucalyptus saligna Smith em São Grabriel, RS. Ecologia e Nutrição Florestal 2014; 2(1): 1-8. 10.5902/2316980X15045

Schumacher MV, Brun EJ, Hernandes JI, König FG. Produção de serapilheira em uma floresta de Araucaria angustifolia (bertol.) kuntze no município de Pinhal Grande-RS. Revista Árvore 2004; 28(1): 29-37. 10.1590/S0100-67622004000100005

Schumacher MV, Witschoreck R, Calil FN. Biomassa em povoamentos de Eucalyptus spp. de pequenas propriedades rurais em Vera Cruz, RS. Ciência Florestal 2011; 21(1): 17-22. $10.5902 / 198050982743$
Schumacher MV, Corrêa RS, Vieira M, Araújo EF. Produção e decomposição de serapilheira em um povoamento de Eucalyptus urophylla $\times$ Eucalyptus globulus maidenii stand. Cerne 2013; 19(3): 501-508. 10.1590/S0104-77602013000300018

Vieira M, Schumacher MV, Caldeira MVW. Dinâmica de decomposição e nutrientes em plantio de Eucalyptus urophylla $\times$ Eucalyptus globulus no Sul do Brasil. Floresta e Ambiente 2013; 20(3): 351-360. 10.4322/floram.2013.021

Vogel HLM, Lorentz LH, Oliveira FP. Serapilheira produzida em um fragmento de uma Floresta Estacional Subtropical no estado do Rio Grande do Sul. Ecologia e Nutrição Florestal 2014; 2(3): 84-92. 10.5902/2316980X16130 